\title{
ПРОКУРАТУРА В КОНСТИТУЦИОННОЙ СИСТЕМЕ СУДЕБНОЙ ВЛАСТИ АЗЕРБАЙДЖАНСКОЙ РЕСПУБЛИКИ
}

ДЖАМАЛОВА Гюнай Таги Гызы - докторант кафедры «Конституционного
права» Бакинского государственного университета (Баку, Азербайджан)

DOI 10.32782/EP.2020.3.2

\begin{abstract}
В статье автор отмечает, что нъинешняя Конститущия Азербайджанской Республики более точно отражает назначение судов и юридическую природу их деятельности - правосудие. При этом, согласно приниипу разделения властей, органъ прокуратуры никак не могут бътть отнесенъ к судебной власти. Далее утверждается, ито прокуратура, участвуюшая в уголовном судопроизводстве как одна из сторон, не может бъть одновременно отнесена и к системе судебной власти. Так как, в первую очередь, это противоречит приниипу разделения властей. Однако, несмотря на все это, норма, озаглавленная «Прокуратура Азербайджанской Республики», предусматривается в главе VII Конституиии Азербайджанской Республики, озаглавленной «Судебная власть». Заключается, ито бъло бы иелесообразнее пересмотреть роль и фбункиии прокуратурь, и в рамках проводимьхх правовьих реформ - возможность включения прокуратуры в состав Министерства юотиции АP.

Ключевъге слова: государство, судебная власть, Конституция, правоохранительныле органъи, функции прокуратурьл, принцип разделения властей, защита прав и свобод
\end{abstract}

Само название «Судебная власть» в Азербайджанской Республике на конституционном уровне появилось впервые.В прежней Конституции Азербайджанской CCP, которая, как и конституции всех союзных республик, была во многом, зеркальным отражением Конституции СССР, соответствующая глава именовалась «Пра- восудие и прокурорский надзор». При всем том, что нынешняя Конституция АР более точно отражает назначение судов и юридическую природу их деятельности - правосудие, включение в эту главу прокуратуры (ст.133 Конституции), вызывает определенные сомнения (1). Возникает вопрос о том, насколько это соответствует функциям прокуратуры и не ведет ли к необоснованному расширению, размыванию содержания понятия «судебная власть».

Согласно принципу разделения властей, органы прокуратуры никак не могут быть отнесены к судебной власти. Поскольку в соответствии со статьей 125-й Конституции АР, правосудие в Азербайджанской Республике осуществляется только судом; судебная власть реализуется посредством конституционного, гражданского, административного и уголовного судопроизводства. Прокуратуру, без достаточных на то оснований, объединяют с органами суда. Нельзя забывать, что органы правосудия разрешают только конкретные индивидуальные дела, они не обеспечивают и не могут обеспечить постоянного и систематического контроля за деятельностью органов государственного управления и должностных лиц. Очевидно, что законность обеспечивается, во-первых, надзором за исполнением законов, а во-вторых, наказанием за неисполнение закона. Из этих задач прокуратуре отведено лишь осуществление надзора, в то время как суд, обеспечивая законность путем рассмотрения уголовных и 


\section{Теорія, історія держави і права, конституційне право}

гражданских дел, призван решать и вторую задачу. Кроме того, включение прокуратуры в состав судебной власти, может привести к нарушению основных принципов процессуального права (состязательности, диспозитивности, равноправия сторон).

О месте прокуратуры в системе разделения власти, существующей в Азербайджанской Республике, следует сказать отдельно. В советский период прокуратура Азербайджанской Советской Социалистической Peспублики находилась сначала в составе Народного комиссариата юстиции, а позже в системе Прокуратуры СССР, что соответствовало законам СССР того времени. В Coветском государстве прокуратура обладала безграничными полномочиями, подменяла полномочия судов и даже конституционного суда, выполняя надзор за соответствием нормативных актов исполнительной власти Конституции и законам. Путь развития на интеграцию в Европейское сообщество, избранный референдумом Азербайджанского народа, не представлялся возможным без реформирования правовой системы, в том числе органов прокуратуры. Однако противодействие консервативных, злоупотребляющих обширными полномочиями, сил создавало значительные трудности в этой работе. В правовом государстве законность и правопорядок предполагают, что всякое действие государственных чиновников, особенно в сфере борьбы с преступностью, должно быть строго регламентировано полномочиями и подлежать контролю. Иными словами, борьба с преступностью может вестись только с соблюдением требований формального судопроизводства, установленных правил и в поисках истины способствовать справедливому суду $(2,67)$.

Общий принцип разделения властей в Азербайджанской Республике нашел своё правое обоснование в Конституции Азербайджанской Республики, принятой 12 ноября 1995 года: законодательная, исполнительная и судебная власть находятся во взаимодействии, но при этом являются самостоятельными в рамках своих полномочий. Статус Прокуратуры Азербайджанской Республики определен статьей 133 Конституции Азербайджанской
Республики, структурирован в системе судебной власти. Прокуратура осуществляет свои полномочия в тесной взаимосвязи с другими отраслями государственной власти. В принятом 07 декабря 1999-го года, новом Законе Азербайджанской Республики «О Прокуратуре» нашли свое правовое обоснование основные цели, принципы и направления деятельности прокуратуры, связанные с этим полномочия, структура и основы их организации, виды и характеры прокурорских актов, включая предупредительные, общие требования к кадрам органов прокуратуры, правовая и социальная защита работников прокуратуры, а также другие вопросы деятельности прокуратуры (3). Прокуратура Азербайджанской Республики, осуществляя свою деятельность по контролю за соблюдением законности, руководствуется принципами равенства прав каждого перед законом, соблюдения и уважения прав и свобод физических лиц, прав юридических лиц, объективности, непредвзятости и ссылки на факты, политического нейтралитета; возбуждает уголовные дела и ведет предварительное следствие, осуществляет процессуальное руководство предварительным расследованием по уголовному делу и обеспечивает соблюдение законов, осуществляет надзор за исполнением и применением законов в деятельности органов дознания.

Еще одна характерная качественная особенность места прокуратуры в системе государственной власти Азербайджанской Республики заключается в ее соотношении с судебными органами. Как справедливо отмечает С.Х.Асланов, несмотря на то, что статья Конституции, посвященная прокуратуре Азербайджанской Республики, помещена в главе о судебной власти (глава 7, статья 133), место прокуратуры в системе государственной власти отличается своеобразными характерными качественными особенностями и обладает чертами, отличающими ее от судебных органов $(4,76)$. Представляется очень важным проанализировать характер и формы отношений между прокуратурой и судебными органами с учетом этих особенностей. Прокуратура Азербайджанской Республики согласно 
части 4 статьи 125 Конституции Азербайджанской Республики участвует в уголовном судопроизводстве в отправлении правосудия, вместе с тем, прокуратура не изолирована от Конституционного суда и конституционного производства, а также от гражданского судопроизводства.

Основные принципы и условия судебной власти определены в главе VII Конституции Азербайджанской Республики. За исключением статьи 133 указанной главы, все остальные статьи касаются судебной системы Азербайджанской Республики, ее структуры, деятельности их полномочий и т.д., а статья 133 целиком посвящена прокуратуре Азербайджанской Республики.

По нашему мнению, включение статьи 133, озаглавленной «Прокуратура Азербайджанской Республики», в главу VII Конституции Азербайджанской Республики, озаглавленной «Судебная власть», создает путаницу. Так как, прокуратура не является органом, осуществляющим судебную власть. Поэтому неправильно относить ее к судебной власти.

В пункте 3 части III статьи 7 Конституции Азербайджанской Республики, провозглашающей организация государственной власти на основе принципа разделения властей, говорится, что судебная власть осуществляется судами Азербайджанской Республики.

Часть I статьи 125 Конституции Азербайджанской Республики конкретно гласит: «судебная власть в Азербайджанской Республике осуществляется посредством правосудия только судами» (5).

В части II указанной статьи определяются субъекты, осуществляющие судебную власть: «судебную власть осуществляют Конституиионный Суд Азербайджанской Республики, Верховныий Суд Азербайджанской Республики, апелляиионньле судъ Азербайджанской $P e$ спублики, общие и другие спеииализированнвие суды Азербайджанской Республики».

В части IV той же статьи определяется статус прокуратуры в уголовном судопроизводстве следующим образом: «в уголовном судопроизводстве участвуют Прокуратура Азербайджанской Республики и сторона защи$m b l »(5)$.
Понятно, что прокуратура, участвующая в уголовном судопроизводстве как одна из сторон, не может быть одновременно отнесена и к системе судебной власти. Так как, в первую очередь, это противоречит принципу разделения властей. Однако, несмотря на все это, норма, озаглавленная «Прокуратура Азербайджанской Республики», предусматривается в главе VII Конституции Азербайджанской Республики, озаглавленной «Судебная власть». Иными словами, прокуратура, представляющая сторону обвинения в уголовном судопроизводстве, относится к системе судебной власти, определяются ее функции, устанавливается порядок назначения прокуроров, их полномочия и т.д.

Следует отметить, что включение прокуратуры в главу о судебной власти Конституции является проблемой не только Азербайджанской Республики из числа стран СНГ и Прибалтики. В конституциях России, Казахстана, Аитвы, Грузии и Армении прокуратура также указывается в составе судебной власти. Одобрительно, что в конституциях Украины, Туркменистана, Таджикистана, Узбекистана, Кыргызстана, Беларуси и Молдовы прокуратура не включена в состав судебной власти, а предусмотрена в отдельной главе, а в конституциях Эстонии и Латвии вообще не отведено место прокуратуре.

Исходя из места и функций прокуратуры в системе государственных органов, можно выделить четыре группы стран:

- страны, где прокуратура находится в составе министерства юстиции (США, Франция, Япония, Польша и т.д.);

- страны, где прокуратура включена в состав судейского корпуса (магистратуры) и находится при судах (Испания, Италия);

- страны, где прокуратура выделена в отдельную систему и подотчетна парламенту (КНДР);

- страны, где прокуратура вообще отсутствует (Великобритания) (6, 631-632).

Включение в Конституцию АР, также как и во многих конституциях государств постсоветского пространства прокуратуры в раздел судебной власти (судебной системы), связано с ролью прокуратуры, кото- 


\section{Теорія, історія держави і права, конституційне право}

рую играла в СССР. С другой стороны, на заре становления новой государственности, в унисон с остатками советской идеологии, показала себя и недоработка юридической техники, которая и отразилась на систематизации (структуре) норм Конституции и тем самым возвышении статуса прокуратуры до ранга конституционно-регулируемого.

В части первой статьи 133 Конституции AP говорится, что Прокуратора AP «осуществляет в предусмотренном законом порядке и случаях надзор за исполнением и применением законов...» (1). То есть, здесь речь идет об общем надзоре. Отметим, что в правовых государствах в качестве средства контроля за чиновничьим аппаратом, используется судебная жалоба гражданина, права которого оказались нарушенными. В результате рассмотрения жалобы суд не только защищает права граждан, но и выявляет нарушения законности в правотворческой и правоприменительной деятельности органов государства.

Данные механизмы отражены и в Конституции AP, а также в Законе Азербайджанской Республики «Об обжаловании в суде решений и действий (бездействий), нарушающих права и свободы граждан» от 11 июня 1999-года, что создает условия для пересмотра указанных полномочий и функций Прокуратуры АР (7).

Естественно, в отличие от процессуально независимого и несменяемого судьи, прокурор гораздо ближе к исполнительной власти. Немаловажным фактом является и то, что прокуратура, являясь правоохранительным органом, ведет следствие, что тоже дает основания относить его к органу близкому по своей природе к исполнительной власти. Кроме того, нужно отметить, что центральные органы исполнительной власти, равно как и вышестоящие органы исполнительной обладают необходимым аппаратом внутренней проверки своей деятельности, а граждане наделены всеми правовыми механизмами защиты своих прав и законных интересов. В статье 26 Конституции АР прямо говорится, что каждый вправе защищать не запрещенными законом способами и средствами свои права и свободы и государство гарантирует защиту прав и свобод каждого. А также статья 60 Конституции гласит, что каждому гарантируется судебная защита его прав и свобод, и что каждый вправе обжаловать в суд решения и действия (или бездействие) государственных органов, политических партий, профессиональных союзов, других общественных организаций и должностных лиц.

Хотелось бы отметить, что на современном этапе развития общества на принципах демократии и правового государства, было бы целесообразнее в корне пересмотреть роль и функции прокуратуры и в рамках проводимых правовых реформ, а учитывая ее природу, возможность включения ее в состав Министерства юстиции.

\section{Митература}

1. Конституция Азербайджанской Республики. Баку: Юридическая литература, 2016, 100 c.

2. Велиев И.В. Прокуратура в системе органов публичной власти: опыт сравнительного исследования по материалам Азербайджанской Республики, Российской Федерации и Республики Казахстан [Электронный ресурс] : дис. ... д-ра юрид. наук ,М.: РГБ, 2007.

3. Закон Азербайджанской Республики «О прокуратуре». Собрание законодательства Азербайджанской Республики. -1999, № 12, ст. 688.

4. Асланов С.X. Прокуратура Азербайджана: Организация, направления деятельности. Баку, 2003.

5. Конституция Азербайджанской Республики (на азербайджанском языке). - Баку: «Хугуг Яйын Әви», 2019.

6. Конституционное (государственное) право зарубежных стран. Отв. ред. Страшун Б.А., М.: Проспект, 1996, 784 с.

7. Закон Азербайджанской Республики «Об обжаловании в суде решений и действий (бездействий), нарушающих права и свободы граждан» от 11 июня 1999-года 


\section{Jamalova Gunay Tagi gizi PROSECUTOR'S OFFICE IN THE CONSTITUTIONAL SYSTEM OF THE JUDICIAL POWER OF THE REPUBLIC OF AZERBAIJAN}

In the article, the author notes that the current Constitution of the Republic of Azerbaijan more accurately reflects the purpose of courts and the legal nature of their activities - justice. At the same time, according to the principle of separation of powers, the prosecution authorities cannot in any way be attributed to the judiciary. It is further argued that the prosecutor's office, which participates in criminal proceedings as one of the parties, cannot be simultaneously attributed to the system of the judiciary.
Since, first of all, this is contrary to the principle of separation of powers. However, despite all this, the norm entitled "Prosecutor's Office of the Azerbaijan Republic" is provided for in Chapter VII of the Constitution of the Azerbaijan Republic, entitled "Judicial Power". It concludes that it would be more expedient to revise the role and functions of the prosecutor's office, and within the framework of ongoing legal reforms - the possibility of including the prosecutor's office in the Ministry of Justice of the Republic of Azerbaijan.

Keywords: state, judiciary, Constitution, law enforcement agencies, prosecution authorities, the principle of separation of powers, protection of rights and freedoms 